\title{
Pengaruh Cangkang Keong Sawah (Pila ampullacea) Terhadap Pembentukan Tulang Baru (Remodeling Tulang)
}

\author{
Edrizal $^{1}$, Desnita $E^{2}$, Geminastiti Surya, L ${ }^{3}$ \\ ${ }^{1}$ Bagian Orthodonti, Fakultas Kedokteran Gigi, Universitas Baiturrahmah \\ ${ }^{2}$ Bagian Farmasi, Fakultas Kedokteran Gigi, Universitas Baiturrahmah \\ e-mail: ekadesnita19@gmail.com \\ ${ }^{3}$ Mahasiswa Fakultas Kedokteran Gigi, Universitas Baiturrahmah
}

\begin{abstract}
Abstrak
Latar belakang: Keong sawah dipercaya oleh masyarakat sebagai obat alternatif yang mampu mengobati banyak penyakit, seperti diabetes, penyakit kuning, liver, maag, kolesterol, dan mencegah osteoporosis, kajian ilmiah lebih mendalam mengenai khasiat keong sawah bagi kesehatan manusia masih belum banyak dilakukan. Semuanya ini masih merupakan data empiris dari pengalaman para pengguna keong sawah. Sehingga perlu dilakukan pengujian ilmiah lebih lanjut. Tujuan: Mengetahui apakah kandungan dalam cangkang keong sawah (Pila ampullacea) dapat mempengaruhi proses remodeling tulang. Metode: Jenis penelitian yang digunakan adalah eksperimental laboratorium dengan rancangan control group post test only design. Populasi penelitian ini menggunakan tikus putih Galur Wistar (Rattus norvegicus L.), dengan jumlah sampel minimal yang diperlukan adalah 4 ekor tikus dari setiap kelompok. Sehingga besar sampel yang digunakan adalah 20 ekor tikus Galur Wistar (Rattus norvegicus L.). Penelitian dilakukan di Laboratorium Farmakologi Universitas Andalas, Laboratorium Patologi Anatomi RSI Siti Rahmah dan Laboratorium Patologi Anatomi Universitas Andalas. Menggunakan uji Oneway ANOVA. Hasil: Diperoleh jumlah rata-rata osteoblas pada kelompok kontrol (-) dengan rata-rata jumlah osteoblas terendah yaitu 14,3 per lima lapang pandang. Peningkatan rata-rata paling tinggi terjadi pada pemberian pilla ampullacea $100 \mathrm{mg}$ yaitu 36,6 per lima lapang pandang. Jumlah rata-rata osteoklas kelompok kontrol (-) juga terlihat paling rendah yaitu 1,55 per lima lapang pandang dan peningkatan rata-rata osteoklas paling tinggi pada pemberian pilla ampullacea $100 \mathrm{mg}$ yaitu 3,25 per lima lapang pandang dan terbukti pemberian sediaan serbuk cangkang keong sawah (Pila ampullacea) dapat mempengaruhi proses remodeling tulang dengan $\mathrm{p}<0,05$. Kesimpulan: terdapat pengaruh pemberian serbuk cangkang keong sawah (Pila ampullacea) dalam proses pembentukan osteoblas dan osteoklas. Terdapat pengaruh yang signifikan pada dosis $100 \mathrm{mg}$.
\end{abstract}

Katakunci : Cangkang keong sawah (Pila ampullacea), Osteoblas, Osteoklas

\section{Abstract}

Background: Rice fields conch is believed by people as an alternative medicine that capable to treat many kind of diseases, such as diabetes, jaundice, liver, ulcer, cholesterol, and preventing osteoporosis, more in-depth scientific studies regarding the efficacy of rice field conch for human health are still not widely done. All of this statement are still empirical data from the experiences of rice field conch users, so it needs further research. Objective: To determine whether the content of the rice field conch shell (Pila ampullacea) can affect the bone remodeling process. Method: Types of research that has been used was laboratory experiment with control group post test only design. The population of this research used white type of rat Galur Wistar (Rattus norvegicus L.), with the minimum number of samples needed are 4 rats from each group. So total of the samples are 20 white rats Galur Wistar (Rattus norvegicus L.). Research conducted at the Pharmacology Laboratory of Andalas University, Anatomical pathology Laboratory Siti rahmah islamic hospital and Anatomical Pathology Laboratory Andalas University using Oneway ANOVA test. Result: The results of the research obtained that the

Email : heme@unbrah.ac.id 
average number of osteoblasts in the control group (-) with the lowest average number of osteoblasts was 14.3 per five fields of view. The highest increase in average occurred in the administration of Pila ampullacea 100 $m g$, which is 36.6 per five fields of view. The average number of osteoclasts in the control group (-) was also seen to be the lowest at 1.55 per five fields of view and the increase of osteoclasts average was highest in the administration of $100 \mathrm{mg}$ of ampullacea, which was 3.25 per five fields of view and it was shown that the supply of rice field conch shell powder (Pila ampullacea) could affect bone remodeling processes with $p<0.05$. Conclusion: There is an effect of giving ground snail shell powder (Pila ampullacea) in the process of forming osteoblasts and osteoclasts. There is a significant effect at the dose of $100 \mathrm{mg}$.

Keywords: rice field conch shell (Pila ampullacea), Osteoblast, Osteoklas 


\section{Pendahuluan}

Angka kejadian patah tulang atau insiden fraktur di Indonesia cukup tinggi, berdasarkan hasil Riset Kesehatan Dasar (RISKESDAS) oleh Badan Penelitian dan Pengembangan Depkes RI tahun 2013 angka kejadian cidera mengalami peningkatan dibandingkan pada hasil tahun 2007. Kasus fraktur yang terjadi di Indonesia disebabkan oleh cedera seperti karena jatuh, kecelakaan lalu lintas dan trauma benda tajam atau tumpul.

Kecenderungan prevalensi cedera menunjukkan sedikit kenaikan dari 7,5\% (RKD 2007) menjadi 8,2 \% (RKD 2013) ${ }^{1}$. Kenyataan diatas terlihat bahwa kebutuhan implan di bidang orthopedi semakin meningkat.

Tulang merupakan jaringan kuat pembentuk kerangka tubuh manusia yang memiliki empat fungsi utama yaitu fungsi mekanik, protektif, metabolik, dan hemopetik. Fungsi mekanik yaitu sebagai penyokong tubuh dan tempat melekatnya jaringan otot untuk pergerakan. Fungsi protektif yaitu sebagai pelindung berbagai alat vital dalam tubuh dan sum sum tulang. Fungsi metabolik yaitu sebagai cadangan dan tempat metabolisme berbagai mineral yang penting seperti kalsium dan fosfat. Fungsi hemopetik yaitu sebagai tempat berlangsungnya proses pembentukan dan perkembangan sel darah ${ }^{2}$.

Hidroksiapatit dapat disintesis dengan menggunakan bahan alami yang mengandung banyak kalsium, antara lain tulang dan cangkang. Menurut Winata (2012), Hidroksiapatit dapat disintesis dari cangkang keong sawah. Cangkang keong merupakan sumber kalsium secara alami dan banyak tersedia di negara Indonesia sehingga dapat dijadikan hidroksiapatit yang lebih murah bagi masyarakat jika dibandingkan dengan produk hidroksiapatit yang harus diimport dari luar negeri ${ }^{3}$.

Keong sawah dipercaya oleh masyarakat sebagai obat alternatif yang mampu mengobati banyak penyakit, seperti diabetes, penyakit kuning, liver, maag, kolesterol, dan mencegah osteoporosis. Kajian ilmiah lebih mendalam mengenai khasiat keong sawah bagi kesehatan manusia masih belum banyak dilakukan. Semuanya ini masih merupakan pembuktian empiris dari pengalaman para pengguna. Sehingga perlu dilakukan pengujian ilmiah lebih lanjut terhadap keong sawah.

Tubuh membutuhkan kalsium, protein, dan fosfor untuk membentuk tulang dan gigi, serta proses biologis pada tubuh lainnya. Kalsium terbesar diperlukan pada saat pertumbuhan dan pembentukan tulang baru (proses aposisi) $^{4}$ Merujuk dari penelitian sebelumnya yang dilakukan oleh Bayu chandra winata (2012) menunjukkan hasil analisis bahwa fase kalsium cangkang keong sawah setelah dikalsinasi adalah $\mathrm{Ca}(\mathrm{OH})_{2}$ dengan kadar kalsium sebesar 52,12\%.

Meskipun beberapa penelitian telah dilaporkan bahwa cangkang keong sawah memiliki kandungan kalsium sebagai hidroksiapatit. Belum ada penelitian yang melaporkan apakah cangkang keong sawah dapat mempercepat proses remodelling pada tulang dengan meningkatkan proses pembentukkan sel osteoblas dan osteoklas. Penelitian ini, di harapkan baik dokter, dokter gigi maupun masyarakat dapat menyadari bahwa kandungan kalsium yang terdapat pada cangkang keong sawah dapat mempercepat proses remodelling tulang sehingga proses penyembuhan tulang dapat lebih cepat. 


\section{Rumusan Masalah}

"Apakah sediaan bubuk cangkang keong sawah (Pila ampullacea) dapat mempengaruhi proses remodeling tulang?"

\section{Tujuan Penelitian}

Untuk mengetahui apakah kandungan dalam cangkang keong sawah (Pila ampullacea) dapat mempengaruhi proses remodeling tulang.

\section{Metode Penelitian}

\section{A. Jenis Penelitian}

Jenis penelitian yang digunakan adalah penelitian eksperimental laboratorium Penelitian ini menggunakan rancangan post test only control group design yaitu melakukan pengukuran setelah perlakuan diberikan dan hasilnya dibandingkan dengan kelompok kontrol ${ }^{5}$.

\section{B. Cara Kerja}

\section{1) Pembuatan Sediaan Bubuk Cangkang Keong Sawah (Pila ampulacea)}

Pembuatan sediaan bubuk cangkang keong sawah, adalah sebagai berikut:

a) Menimbang $1 \mathrm{~kg}$ cangkang keong kemudian dicuci dan dikeringkan.

b) Dipanaskan pada suhu $800^{\circ} \mathrm{C}$ selama 3 jam, lalu didinginkan sampai suhu ruang.

c) Cangkang keong sawah (Pila ampulacea) di tumbuk dan digerus menggunakan labu yang terbuat dari kayu sampai halus dan berbentuk bubuk.

d) Hasil dari penghalusan cangkang keong sawah (Pila ampulacea) dimasukan ke dalam toples kedap udara.

\section{2) Penyiapan Hewan Percobaan}

Pada penelitian ini menggunakan hewan coba berupa tikus putih (Rattus norvegicus) jantan Galur Wistar berumur 12 minggu.
Berat badan tikus sekitar 200 gram. Hewan coba dipelihara dalam kandang yang disekat sekat, dengan ukuran panjang dan lebar kandang lebih panjang dari tubuh hewan dan tiap kandang dialasi dengan sekam padi. Terdapat 20 kandang, tiap kandang ditempatkan 1 ekor betina. Hewan coba di aklimatisasi dengan pemberian makanan berupa ransum basal dan minum air suling secara ad libitum pada semua tikus. Kandang dibersihkan dan alas sekam diganti setiap dua hari. Tempat makan dan minuman dibersihkan dan diganti tiap hari.

\section{3) Perlakuan Sampel Penelitian}

Hewan percobaan dikelompokkan menjadi 5 kelompok yang masing masing kelompok terdiri dari 4 ekor tikus, tiap hewan percobaan:

a) Kelompok I:

Pengamatan fraktur pada tikus perlakuan I, tikus yang dipatahkan tibianya dan dipertahankan selama 1 bulan tanpa diberi bubuk cangkang keong (K-).

b) Kelompok II:

Pengamatan fraktur pada tikus perlakuan II, tikus yang dipatahkan tibianya dan dipertahankan selama 1 bulan, diberi bubuk cangkang keong dengan dosis 70 $\mathrm{mg}(\mathrm{P} 1)$.

c) Kelompok III:

Pengamatan fraktur pada tikus perlakuan II, tikus yang dipatahkan tibianya dan dipertahankan selama 1 bulan, diberi bubuk cangkang keong dengan dosis 80 mg (P2).

d) Kelompok IV:

Pengamatan fraktur pada tikus perlakuan III, tikus yang dipatahkan tibianya dan dipertahankan selama 1 bulan dan diberi bubuk cangkang keong dengan dosis 90 $\mathrm{mg}$ (P3).

e) Kelompok V:

Pengamatan fraktur pada tikus perlakuan IV, tikus yang dipatahkan tibianya dan dipertahankan selama 1 bulan dan diberi bubuk cangkang keong dengan dosis 100 mg (P4). 


\section{4) Pembuatan Sediaan Histologi}

Menurut (Muntha, 2001) proses pembuatan preparat histologi untuk melihat dan menghitung nilai pembentukan osteoblas, sebagai berikut ${ }^{6}$ :

a) Memotong jaringan organ setelah jaringan organ yang berada di dalam larutan fiksatif matang, jangan ditiriskan mengunakan saringan selanjutnya dipotong menggunakan pisau scalpel dengan ketebalan $0,3-0,5 \mathrm{~mm}$ dan disusun ke dalam keranjang khusus (basket).

b) Proses Dehidrasi Keranjang (basket) yang didalamnya berisi jaringan organ, dimasukan ke dalam mesin processor otomatis. Selanjutnya jaringan mengalami proses dehidrasi bertahap dengan putaran waktu sebanyak berikut : ethanol $70 \%$ (2 jam), ethanol 80\% (2 jam), ethanol $90 \%$ (2 jam), ethanol absolut (2 jam), ethanol absolut (2 jam), xylol (2 jam), parafin cair (2 jam), parafin cair (2 jam). Selanjutnya keranjang yang berisi tissue casstelle dikeluarkan untuk melanjutkan proses berikutnya.

c) Vakum

Setelah proses dilakukan, kemudian dilanjutkan dengan penghilangan udara dari jaringan dan menggunakan mesin vakum yang didalamnya terdapat tabung untuk menyimpan keranjang yang diisi paraffin cair dengan temperature $60^{\circ} \mathrm{C}$ untuk sementara waktu sebelum pencetakan dilakukan dengan paraffin cair.

d) Mencetak blok paraffin

Cetakan dari bahan stainless steel dihangatkan di atas api bunsen, lalu ke dalam setiap cetakan dimasukan jaringan sambil diatur dan sedikit ditekan. Sementara itu ditempat lain telah disiapkan paraffin cair dalam tempat khusus, sehingga dicapai suhu $60^{\circ} \mathrm{C}$. Paraffin cair tersebut di tuangkan ke dalam jaringan sampai seluruh jaringan terendam paraffin. Paraffin dibiarkan membeku di atas mesin pendingin.
Selanjutnya blok paraffin dilepas dari cetakan dan disimpan di freezer $\left(-20^{\circ} \mathrm{C}\right)$ sebelum dilakukan pemotongan.

e) Memotong blok jaringan

Blok paraffin yang mengandung jaringan, kemudian dipotong dengan menggunakan mesin mikrotom dengan ketebalan $\pm 3-4 \mu \mathrm{m}$. Potongan tersebut diletakkan secara hati hati di atas permukaan air dalam waterbath bersuhu $46^{\circ} \mathrm{C}$. Pada kesempatan ini bentuk irisan dirapikan, kemudian diletakkan di atas kaca obyek yang telah diolesi ewith yang berfungsi sebagai bahan perekat, kaca obyek dengan jaringan di atasnya disusun di dalam rak khusus dan dimasukkan ke dalam inkubator bersuhu $60^{\circ} \mathrm{C}$ sampai preparat siap diwarnai. Jumlah sel sel osteoblas diperiksa secara mikroskopis dengan pembesaran 400 kali.

\section{5) Perhitungan Sel Osteoblas dan Sel Osteoklas}

Sel-sel osteoblas dan osteoklas pada permukaan tulang tibia dari masing-masing preparat diperiksa di bawah mikroskop dalam lima lapang pandang. Sel-sel osteoblas dan osteoklas dari lima lapang pandang dijumlahkan lalu hasilnya dibagi lima untuk mencari rataan jumlah sel-sel osteoblas dan osteoklas ${ }^{7}$.

\section{Analisa Data}

\section{1) Analisis Deskriptif}

Data hasil perhitungan sel sel osteoblas akan disajikan dalam bentuk tabel dan grafik.

\section{2) Analisa Statistik}

Normalitas distribusi data diuji dengan Shapiro-Wilk ( $<<50)$, homogenitas data dilakukan dengan Levene's test untuk menentukan apakah data tersebut homogen atau tidak. Data pengamatan yang diperoleh dianalisis secara statistik untuk mengetahui adanya perbedaan jumlah sel osteoblas dan 
osteoklas dari masing- masing kelompok sampel dengan menggunakan uji one way ANOVA dan uji LSD. Apabila data tidak terdistribusi normal, maka dilakukan Uji Kruskal-Wallis.

\section{Hasil dan Pembahasan}

\section{A. Hasil Penelitian}

Berdasarkan penelitian yang telah dilakukan untuk melihat pengaruh pemberian sediaan bubuk cangkang keong sawah (Pila ampullacea) terhadap proses remodeling tulang dengan menggunakan kontrol (-), sediaan bubuk cangkang keong sawah 70 $\mathrm{mg}, 80 \mathrm{mg}, 90 \mathrm{mg}$ dan $100 \mathrm{mg}$ diperoleh hasil sebagai berikut:

TABEL 1. JUMLAH RATA-RATA OSTEOBlas DAN OSTEOKLAS PADA KELOMPOK KONTROL (-) PERLAKUAN I, II, III DAN IV

\begin{tabular}{llll}
\hline & & \multicolumn{2}{c}{ Mean \pm Std. Deviasi } \\
\cline { 2 - 4 } No & Kelompok & Osteoblas & Osteoklas \\
& & $14,3 \pm 1,148$ & $1,55 \pm 0,341$ \\
\hline 1 & Kontrol (-) & & \\
2 & Pila ampullacea $70 \mathrm{mg}$ & $26,2 \pm 1,526$ & $1,90 \pm 0,200$ \\
3 & Pila ampullacea $80 \mathrm{mg}$ & $26,4 \pm 1,275$ & $2,00 \pm 0,230$ \\
4 & Pila ampullacea $90 \mathrm{mg}$ & $34,8 \pm 7,131$ & $3,00 \pm 0,673$ \\
5 & Pila ampullacea $100 \mathrm{mg}$ & $36,6 \pm 6,389$ & $3,25 \pm 0,619$ \\
\hline
\end{tabular}

Pada tabel 1 menunjukan bahwa jumlah rerata osteoblas pada kelompok kontrol (-) rerata jumlah osteoblas terendah yaitu 14,3 per lima lapang pandang. Peningkatan rerata paling tinggi terjadi pada pemberian cangkang keong sawah (Pila ampullacea) $100 \mathrm{mg}$ yaitu 36,6 per lima lapang pandang.

Jumlah rerata osteoklas kelompok negatif juga terlihat paling rendah yaitu 1,55 per lima lapang pandang dan peningkatan rerata osteoklas paling tinggi pada pilla $100 \mathrm{mg}$ yaitu 3,25 per lima lapang pandang.

Grafik Perbandingan Sel Osteoblas dan Osteoklas

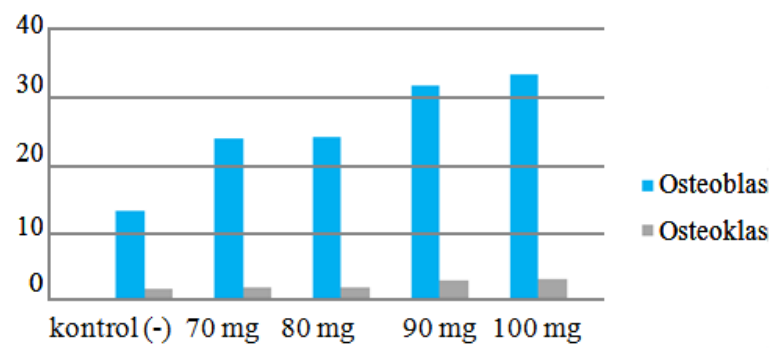

Grafik 1. Pembentukan Sel Osteoblas dan OSTEOKLAS

Gambaran histopatologis memberikan kesan;

1) Terdapat perbedaan pada gambaran reaksi osteoblas dan osteoklas antar kelompok, (kontrol dan perlakuan pada sampel penelitian. Perbedaan meliputi;

a) Osteoblas; terdapat peningkatan jumlah (proliferasi) osteoblas baik pada kelompok dengan perlakuan dibandingkan kontrol. Peningkatan jumlah osteoblast tampak paling tinggi pada kelompok perlakuan dengan serbuk cangkang keong sawah (Pila ampullacea) $100 \mathrm{mg}$, diikuti kelompok perlakuan dengan $90 \mathrm{mg}$. Jumlah osteoblat pada kelompok perlakuan dengan konsentrasi 70 dan $80 \mathrm{mg}$ lebih rendah dibanding perlakuan 90 dan $100 \mathrm{mg}$ namun lebih tinggi dibanding kontrol.

b) Osteoklas; terdapat pertambahan jumlah osteoklas pada hewan perlakuan dengan cangkang keong sawah dibanding kontrol, peningkatan jumlah osteoklas tampak paling tinggi pada kelompok perlakuan dengan serbuk cangkang keong sawah (Pila ampullacea) 100 mg. Jumlah osteoblas pada kelompok perlakuan dengan konsentrasi $70 \mathrm{mg}$ dan $80 \mathrm{mg}$ lebih rendah dibanding perlakuan $90 \mathrm{mg}$ dan $100 \mathrm{mg}$ namun lebih tinggi dibanding kontrol.

c) Infiltrasi sel radang, jaringan kalus dengan perlakuan serbuk cangkang keong sawah (Pila ampullacea) memperlihatkan jumlah sel radang baik leukosit PMN maupun limfosit 
dan histiosit yang lebih banyak dibanding jaringan kontrol.

d) Desmoplasia; jaringan kalus dengan perlakuan serbuk cangkang Pilla ampulaceae memperlihatkan proliferasi jaringan ikat (fibrosis) yang lebih banyak dibanding jaringan kontrol.

2) Terdapat perubahan jumlah Osteoblas maupun osteoklas pada kelompok perlakuan, dengan pemberian serbuk cangkang keong sawah (Pila ampullacea) dibanding kontrol. Terdapat kemungkinan pengaruh induksi proliferasi pertumbuhan osteoblas maupun osteoklas akibat pemberian serbuk cangkang keong sawah (Pila ampullacea).

3) Terdapat pula perbedaan infiltrasi sel radang serta fibrosis jaringan ikat pada kalus pada kelompok perlakuan yang memberikan kesan adanya cangkang Pilla ampulaceae terhadap inflamasi dan deposit jaringan ikat. Adanya benda asing seperti material cangkang hewan pada daerah sekitar luka/fraktur dapat merangsang timbulnya reaksi radang dan granuloma benda asing. Peradangan ini akan diikuti oleh fibrosis.

4) Adanya peradangan disekitar kallus dapat menginduksi secara tidak langsung proliferasi sel mesenkim termasuk osteoblas maupun osteoklas. Hal ini perlu dipertimbangkan sebagai salah satu mekanisme lain perangsangan proliferasi sel setelah pemberian cangkang keong sawah (Pila ampullacea), selain efek langsung dari kandungan sebuk cangkang keong sawah (Pila ampullacea) pada sel osteoblas dan osteoklas. Perlu dilakukan penelitian lebih lanjut terhadap hal ini.

5) Penghitungan menggunakan sediaan yang diwarnai dengan pewarnaan Hematoksilin-eosin. Walaupun sel dapat dibedakan berdasarkan morfologi dan ukuran, sebagian sel sukar dibedakan secara pasti pada pewarnaan HE, sel-sel ini mungkin ikut terhitung dalam penghitungan dan terhitung sebagai osteoblas ataupun osteoklas walaupun proporsinya kecil

a) histiocyte, myofibroblast dapat menyerupai osteoblas,

b) sel datia benda asing dapat menyerupai osteoclas.

Untuk penelitian lanjutan jika diinginkan penghitungan yang lebih akurat terhadap osteoblas diperlukan pemeriksaan histopatologis lanjut berupa immunohistokimia dengan marker sel spesifik.

Data yang didapatkan pada hasil pengamatan dilakukan uji normalitas. Uji normalitas yang digunakan adalah Shapiro-wilk test karena data kurang dari 50 dan didapatkan hasil uji jumlah sel osteoblas dan osteoklas pada setiap kelompok $\mathrm{P}>0,05$. Dengan demikian dapat disimpulkan bahwa data yang diperoleh terdistribusi normal.

Tabel 2. UJI NoRMalitas Data OSTEOblas daN OSTEOKLAS PADa SETIAP KELOMPOK PERLAKUAN

\begin{tabular}{cccc}
\hline & \multicolumn{3}{c}{ Shapiro-Wilk } \\
\cline { 2 - 4 } & Statistic & Df & Sig. \\
\hline Osteoblas & 0,93 & 20 & 0,156 \\
Osteoklas & 0,923 & 20 & 0,114 \\
\hline
\end{tabular}

Dilakukan uji homogenitas dengan Levene's test untuk menentukan apakah data tersebut homogen atau tidak. Hasil uji homogenitas variasi didapatkan hasil yang signifikan $\mathrm{P}>0,05$. Jadi, dapat disimpulkan bahwa data dari semua kelompok adalah homogen.

TABEl 3. UJI HOMOgENITAS DATA OSTEOBLAS DAN OSTEOKLAS

\begin{tabular}{cc}
\hline Variabel & Sig. \\
\hline Osteoblas & 0,076 \\
Osteoklas & 0,191 \\
\hline
\end{tabular}

Selanjutnya dilakukan uji parametrik Oneway ANOVA dengan taraf kepercayaan $\mathrm{p}=0,05$. Berdasarkan hasil uji parametrik Oneway ANOVA diperoleh $\mathrm{p}<0,05$, dalam 
hal ini terdapat perbedaan bermakna antara kelompok kontrol dan kelompok perlakuan terhadap jumlah osteoblas dan osteoklas.

Tabel 4. Hasil UJI oneway anova Data OSTEOBLAS DAN OSTEOKLAS

\begin{tabular}{cccc}
\hline No. & Pembentukan sel & Sig & Batas Sig \\
\hline 1 & Osteoblas & 0,000 & 0,05 \\
2 & Osteoklas & 0,004 & 0,05 \\
\hline
\end{tabular}

Untuk mengetahui lebih lanjut perbedaan masng-masing variabel maka dilanjutkan dengan uji LSD (Least Significance Different) untuk mengetahui besarnya perbedaan tiap kelompok.

Tabel 5. Ringkasan Signifikan UJI Beda LSD TERHADAP RERTA JUMLAH OSTEOBLAST

\begin{tabular}{|c|c|c|c|c|}
\hline \multirow{2}{*}{ Variabel } & \multirow{2}{*}{ Perlakuan } & $\begin{array}{c}\text { Perbandingan } \\
\text { Konsentrasi } \\
\end{array}$ & \multirow[t]{2}{*}{ Sig } & \multirow{2}{*}{$\begin{array}{c}\text { Batas } \\
\text { Sig }\end{array}$} \\
\hline & & Antra Ekstrak & & \\
\hline \multirow[t]{10}{*}{ Osteoblas } & Kontrol & Pilla $70 \mathrm{mg}$ & $* 0,001$ & 0.05 \\
\hline & negatif & Pilla $80 \mathrm{mg}$ & $* 0,002$ & 0.05 \\
\hline & & Pilla $90 \mathrm{mg}$ & $* 0,000$ & 0.05 \\
\hline & & Pilla $100 \mathrm{mg}$ & $* 0,000$ & 0.05 \\
\hline & Pilla $70 \mathrm{mg}$ & Pilla $80 \mathrm{mg}$ & 0,962 & 0.05 \\
\hline & & Pilla $90 \mathrm{mg}$ & $* 0,005$ & 0.05 \\
\hline & & Pilla $100 \mathrm{mg}$ & $* 0,017$ & 0.05 \\
\hline & Pilla $80 \mathrm{mg}$ & Pilla $90 \mathrm{mg}$ & $* 0,005$ & 0.05 \\
\hline & & Pilla $100 \mathrm{mg}$ & $* 0,015$ & 0.05 \\
\hline & Pilla $90 \mathrm{mg}$ & Pilla $100 \mathrm{mg}$ & 0,572 & 0.05 \\
\hline \multirow[t]{10}{*}{ Osteoklas } & Kontrol & Pilla $70 \mathrm{mg}$ & 0,296 & 0.05 \\
\hline & negatif & Pilla $80 \mathrm{mg}$ & 0,185 & 0.05 \\
\hline & & Pilla $90 \mathrm{mg}$ & $* 0,000$ & 0.05 \\
\hline & & Pilla 100 mg & $* 0,000$ & 0.05 \\
\hline & Pilla $70 \mathrm{mg}$ & Pilla $80 \mathrm{mg}$ & 0,761 & 0.05 \\
\hline & & Pilla $90 \mathrm{mg}$ & $* 0,004$ & 0.05 \\
\hline & & Pilla 100 mg & $* 0,001$ & 0.05 \\
\hline & Pilla $80 \mathrm{mg}$ & Pilla $90 \mathrm{mg}$ & $* 0,007$ & 0.05 \\
\hline & & Pilla 100 mg & $* 0,002$ & 0.05 \\
\hline & Pilla $90 \mathrm{mg}$ & Pilla $100 \mathrm{mg}$ & 0,452 & 0.05 \\
\hline
\end{tabular}

Berdasarkan uji LSD menunjukan pada kelompok pengukuran osteoblast dan osteoklas adanya perbedaan yang bermakna antara kelompok kontrol (-) dengan perlakuan I, perlakuan II, III dan IV dan sebaliknya.

\section{B. Pembahasan}

Berdasarkan hasil pengujian yang telah dilakukan terhadap spesimen tulang tibia tikus putih Galur wistar terhadap sediaan bubuk cangkang keong sawah (Pila ampullacea), dapat mempengaruhi proses remodeling tulang. Terbukti bahwa terdapat perbedaan bermakna antara kelompok kontrol dan kelompok perlakuan terhadap jumlah sel osteoblas dan sel osteoklas dimana pada kelompok pembentukan sel osteoblas, perlakuan dengan rerata tertinggi pada cangkang keong sawah (Pila ampullacea) $100 \mathrm{mg}$ dan pada osteoklas dengan perlakuan $100 \mathrm{mg}$. Artinya semakin tinggi dosis bubuk yang diberikan maka semakin baik pembentukan sel osteoblas dan osteoklas proses remodeling tulang.

Berdasarkan rerata pada sel osteoblas kontrol negatif memiliki rerata terendah yaitu 14,3 , pada cangkang keong sawah (Pila ampullacea) $70 \mathrm{mg}$ rerata sel osteoblas meningkat menjadi 26,2, pada cangkang keong sawah (Pila ampullacea) $80 \mathrm{mg}$, sel osteoblas semakin meningkat menjadi 26,4 , pada cangkang keong sawah (Pila ampullacea) $90 \mathrm{mg}$, sel osteoblas bertambah meningkat menjadi 34,8 dan pada cangkang keong sawah (Pila ampullacea) $100 \mathrm{mg}$ sel osteoblas semakin meningkat menjadi 36,6. Hal ini menunjukan bahwa pembentukan sel osteoblas terbaik adalah pada pemberian cangkang keong sawah (Pila ampullacea) $100 \mathrm{mg}$.

Rerata sel osteoklas kontrol negatif memiliki rerata terendah yaitu 1,55, pada cangkang keong sawah (Pila ampullacea) 70 mg rerata sel osteoklas meningkat menjadi 1,90, cangkang keong sawah (Pila ampullacea) $80 \mathrm{mg}$ sel osteoklas semakin meningkat menjadi 2,0, cangkang keong sawah (Pila ampullacea) $90 \mathrm{mg}$ sel osteoklas bertambah meningkat menjadi 3,00 dan pada cangkang keong sawah (Pila ampullacea) $100 \mathrm{mg}$ sel osteoklas semakin meningkat menjadi 3,25. Hal ini menunjkan bahwa pembentukan sel osteoklas terbaik juga pada 
pemberian cangkang keong sawah (Pila ampullacea) $100 \mathrm{mg}$.

Tingkat keberhasilan proses penyembuhan tulang ditandai dengan terbentuknya matriks tulang baru yang disekresikan oleh osteoblas yang kemudian akan terosifikasi. Osteoblas merupakan sel pembentuk tulang yang bertanggung jawab terhadap proses mineralisasi matriks tulang dengan cara mensekresi kolagen tipe I dan melepaskan kalsium, magnesium, dan ion fosfat ${ }^{8}$.

Terbukti bahwa bubuk cangkang keong sawah (Pila ampullacea) dapat mempengaruhi proses remodeling tulang, hal ini disebabkan karena cangkang keong sawah mengandung kalsium. Kalsium adalah mineral penting yang paling banyak dibutuhkan bagi tubuh. Kalsium sebagai nutrisi memegang peranan sangat penting dalam pola diet sehat dan kandungan mineral dalam tubuh. Beberapa zat dalam makanan seperti protein, asam amino, vitamin D3, dan laktat dapat meningkatkan penyerapan kalsium. Peranan kalsium dalam tubuh pada umumnya dapat dibagi menjadi dua, yaitu membantu membentuk tulang gigi dan mengatur proses biologis keperluan keperluan kalsium masih diteruskan meskipun sudah mencapai usia dewasa. Pada pembentukan tulang, bila tulang baru dibentuk maka tulang yang tua dihancurkan secara simultan ${ }^{9}$.

Keong sawah (Pila ampullacea) memiliki nilai gizi yang baik karena mengandung kalsium yang cukup tinggi. Banyak masyarakat yang beranggapan bahwa hewan ini merupakan hama bagi tanaman padi. Padahal dengan kandungan gizi yang ada dapat dimanfaatkan sebagai sumber pangan yang baru.

Cangkang keong sawah merupakan sumber kalsium alami, hal inilah yang diduga menyebabkan nilai osteoblas pada kelompok perlakuan cangkang keong sawah $70 \mathrm{mg}, 80$ $\mathrm{mg}, 90 \mathrm{mg}$ dan $100 \mathrm{mg}$ lebih tinggi dibandingkan dengan kelompok kontrol.
Kandungan kalsium dan fosfor dari cangkang keong sawah secara nyata mampu meningkatkan sel osteoblas, peningkatan sel osteoblas mendorong proses pembentukan tulang baru terjadi lebih cepat.

\section{KESIMPUlan DAN SARAN}

\section{A. Kesimpulan}

Berdasarkan penelitian yang telah dilakukan dapat disimpulkan bahwa terdapat pengaruh pemberian serbuk cangkang keong sawah (Pila ampullacea) dalam proses pembentukan osteoblas dan osteoklas. Terdapat pengaruh yang signifikan pada dosis $100 \mathrm{mg}$.

\section{B. Saran}

Berdasarkan hasil penelitian ini maka peneliti menyaran kepada penelitian selanjutnya bahwa :

1) Melakukan penelitian lebih lanjut tentang manfaat lain dari kandungan bubuk cangkang keong sawah (Pila ampullacea) terhadap kesehatan gigi.

2) Melakukan penelitian lebih lanjut dengan jumlah sampel yang lebih banyak dan jangka waktu penelitian yang lebih lama.

3) Melakukan penelitian lebih lanjut dengan pemberian dosis bubuk cangkang keong sawah (Pila ampullacea) yang lebih ditingkatkan.

Melakukan penelitian lebih lanjut dengan bantuan uji rontgen untuk memastikan bubuk cangkang keong sawah (Pila ampullacea) berada tepat di daerah fraktur.

\section{Daftar Pustaka}

[1] Riset Kesehatan Dasar (Riskesdas). (2013). Badan Penelitian dan Pengembangan Kesehatan Kementerian RI.

[2] Mescher, 2011. Histologi Dasar Junqueira, Teks dan Atlas, Edisi 12. EGC. Jakarta.

[3] Winata, Bayu C. 2012. Sintesis dan Karakteristik Hidroksiapatit dari Cangkang Keong Sawah (Pila Ampullacea). Skripsi, Institut Pertanian Bogor, Bogor.

[4] Amrullah, Fahmi. (2012). Kadar Protein dan Ca pada Ikan Teri Asin Hasil Pengasinan dengan 
Abu pelepah Kelapa. UMS Press. Surakarta. Hal: 8 - 11.10.1016/j.abb.2014.05.003.

[5] Notoatmojo, Soekidjo. (2005). Metode Penelitian Kesehatan. PT Rineka Cipta Jakarta. Hal: $66-88$.

[6] Muntha, M. 2001. Teknik Pembuatan Preparat Histopatologi Dari Jaringan Hewan Dengan Pewarnaan Hemotoksilin dan Eosin. Balai Penelitian Veteriner Jurnal Temu Teknis Fungsional Non Peneliti. Hal: 158-160.

[7] Muliani, K, N, M., Tirtayasa, K. 2014. Pemberian Kalsium Laktat dan Berenang Meningkatkan Osteoblast pada Epiphysis Tulang radius Veteriner. Jurna Veteriner. Vol. 15. No. 1. Hal: 39-45.

[8] Kalfas, I. H., 2001, Principles of Bone.

[9] Pudjiastuti, Lestari. (2015). Sintesis Hidroksiapatit dari Cangkang Keong Sawa (Bellamya javanica) dengan Metode Simultan Prespitasi Pengaduka Berganda. Skripsi. Institut Pertanian Bogor. Bogor. 